\title{
PERANCANGAN BOOST CONVERTER DENGAN LDR SEBAGAI PENGENDALI SINYAL PWM UNTUK MENAIKAN TEGANGAN PANEL SURYA
}

\author{
Calvin Yobel Sirait ${ }^{1}$, Hendi Matalata ${ }^{2}$ \\ ${ }^{1}$ Jurusan Teknik Listrik, Fakultas Teknik, Universitas Batanghari \\ ${ }^{2}$ Dosen Teknik Listrik, Fakultas Teknik, Universitas Batanghari \\ e-mail: : pinraitt@gmail.com, hendi.matalata@unbari.ac.id
}

\begin{abstract}
ABSTRAK
Boost Converter adalah perangkat catu daya listrik untuk menaikan tegangan DC (Direct Current), teknologi Boost Converter ini berdasarkan pada mode pensaklaran menggunakan pembangkitan sinyal PWM (Pulse Width Modulation )yang diperuntukan kepada komponen saklar daya pada rangkaian Boost Converter, sinyal PWM ini mempunyai duty cycle untuk memberikan kendali pada kenaikan keluaran tegangan. Pada penelitian ini pengaturan duty cycle menggunakan LDR (Light Dependent Resistor), yang mana pada fungsinya LDR akan mempunyai nilai hambatan yang besar dalam keadaan gelap dan mempunyai nilai hambatan yang kecil dalam keadaan terang. Hasil pengujian yang dilakukan LDR mampu memberikan perubahan duty cycle terhadap perubahan intensitas matahari sehingga perancangan Boost Converter pada penelitian ini mampu menaikan besar tegangan keluaran pada panel surya
\end{abstract}

kata kunci: Boost Converter, PWM, duty cycle, LDR

\section{PENDAHULUAN}

Energi surya merupakan energi baru terbarukan dimana dalam pemanfaatan-nya selalu di optimalkan karena intensitas cahaya dari energi surya yang tidak selalu konstan, sel surya atau komponen panel surya adalah komponen yang dapat mengubah besar intensitas sinar matahari menjadi energi listrik yang bisa dimanfaatkan secara langsung oleh beban atau juga sebagai charger baterai sehingga energi listrik tersebut dapat disimpan, keadaan intensitas matahari yang tidak selalu konstan mengakibatkan terjadinya penurunan energi listrik dari panel surya sehingga proses charger pada baterai tidak optimal, untuk itu diperlukan sebuah rangkaian elektronika daya sebagai penguat umpan balik panel surya.

Aplikasi elektronika daya dewasa ini sangat banyak digunakan salah satu diantaranya adalah DC Chopper. DC Chopper ini mempunyai banyak aplikasi. Aplikasi yang sudah ada sekarang ini adalah DC Chopper sebagai catu daya searah yang dapat diregulasi, dimana catu daya searah yang digunakan adalah catu daya searah bisa dinaikkan dan diturunkan sesuai dengan kebutuhan. Dengan memanfaatkan komponen saklar daya yaitu MOSFET maka kita bisa mengatur besar keluaran dari catu daya searah ${ }^{[2]}$ melalui pengaturan lebar pulsa atau PWM yang diberikan pada gate MOSFET, $D C$ Chopper pada Penelitian ini dirancang tipe Boost converter . DC Chopper yang dirancang dilengkapi dengan penguatan umpan balik (feedback) dengan mengatur lebar pulsa pada gate MOSFET dari rangkaian daya, semakin besar lebar pulsa dari rangkaian PWM yang dibangkitkan maka keluaran catu daya semakin besar pula. Pengaturan lebar pulsa PWM menggunakan sebuah tranduser LDR untuk mengidentifikasikan keadaan intensitas matahari, jika intensitas matahari berkurang maka dengan pengindaraan komponen LDR dapat menaikan lebar pulsa PWM 
sehingga keluaran dari panel surya tidak menurun.

\section{TINJAUAN PUSTAKA}

\subsection{Boost Converter}

Defenisi Boost converter menurut Melzi Ambar Marta, dkk (2016 : 22) adalah sebagai berikut:

"Boost converter merupakan konverter DC-DC yang berfungsi untuk menaikan tegangan".

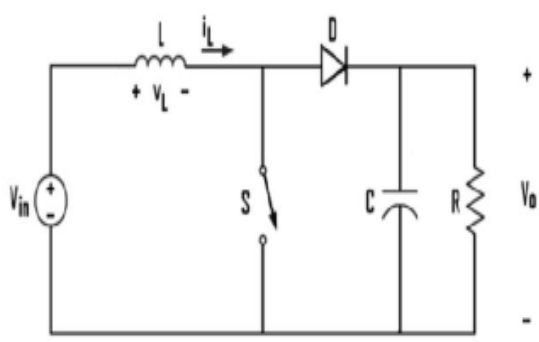

Gambar 1 Rangkaian boost converter[2]

Gambar 1 diatas merupakan gambar rangkaian boost coverter, untuk mempermudah dalam menganalisa rangkaian boost, gambar 1 berikut ini merupakan state dari rangkaian boost pada state $\mathrm{ON}$ dan state $\mathrm{OFF}$.

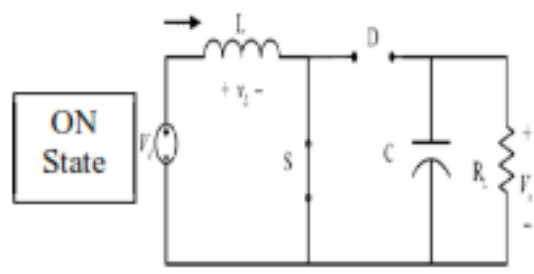

a. State $O N$

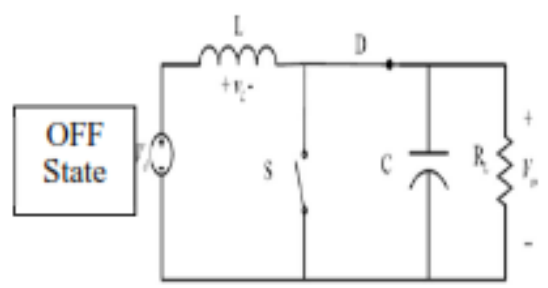

b. State $O F F$

Gambar 2 Rangkaian boost pada saat a.state $O N$ dan b. state OFF[2]

Untuk mendesain boost converter perlu ditetapkan beberapa variabel, yaitu tegangan masukan, tegangan keluaran, arus keluaran, frekuensi switching, ripple tegangan keluaran, dan ripple arus masukan. Dalam menentukan besarnya nilai induktor dan kapasitor dapat menggunakan persamaan berikut :

$C=\frac{V_{o} \cdot D}{R \Delta V_{o} \cdot f} \ldots \ldots . .$.
$L=\frac{V_{\text {in }} \cdot D(1-D)}{f \cdot \Delta I_{\text {in }}} .$.

Dimana :

$\mathrm{v}_{\mathrm{o}} \quad=$ Tegangan keluaran

$\mathrm{v}_{\text {in }} \quad=$ Tegangan masukan

$\mathrm{D}=$ Duty cycle

$\mathrm{L} \quad=$ Nilai induktor (induktansi)

$\Delta \mathrm{I}_{\text {in }}=$ Riple arus

$\mathrm{F} \quad=$ frekuensi switching

$\mathrm{C}=$ Nilai kapasitor

\subsection{LDR (Light Dependent Resistor)}

LDR adalah singkatan dari Light Dependent Resistor yang merupakan salah satu jenis komponen resistor yang nilai resistansinya dapat berubah-ubah sesuai dengan intensitas cahaya. Komponen LDR biasanya juga disebut dengan photo resistor, atau photocell. Nilai resistansi LDR sangat dipengaruhi oleh intensitas cahaya. Semakin banyak cahaya yang mengenainya, maka semakin menurun nilai resitansinya. Sebaliknya, jika cahaya yang mengenainya sedikit (gelap), maka nilai hambatannya menjadi semakin besar, sehingga arus listrik yang mengalir akan terhambat. Pada umumnya sebuah LDR memiliki nilai hambatan 200 Kilo Ohm saat berada di kondisi minim cahaya (gelap), dan akan menurun menjadi 500 Ohm pada kondisi terkena cahaya. Tak heran jika komponen yang satu ini banyak diaplikasikan pada rangkaian dengan tema saklar otomatis dari cahaya.

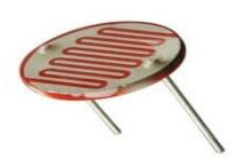

Gambar 3. Simbol dan Bentuk Fisik LDR 


\subsection{Pulse Width Modulation (PWM)}

Sinyal PWM pada umumnya memiliki amplitudo dan frekuensi dasar yang tetap, namun memiliki lebar pulsa yang bervariasi. Lebar Pulsa PWM berbanding lurus dengan amplitudo sinyal asli yang belum termodulasi. Artinya, Sinyal PWM memiliki frekuensi gelombang yang tetap namun duty cycle bervariasi (antara 0\% hingga 100\%).

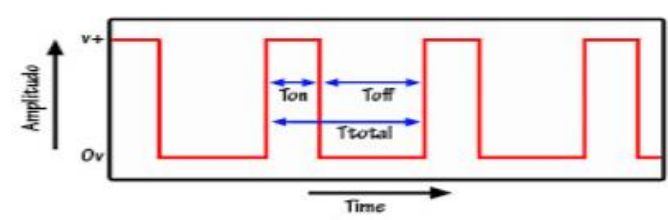

Gambar 4. sinyal PWM[2]

$T_{\text {total }}=T_{\text {on }}+T_{\text {off }}$

$D=\frac{T_{\text {on }}}{T_{\text {total }}}$

$V_{\text {out }}=D x V_{\text {in }}$

Dimana :

$\mathrm{T}_{\mathrm{on}} \quad=$ waktu pulsa high

$\mathrm{T}_{\text {off }}=$ waktu pulsa low

$\mathrm{D}=$ duty cycle adalah lama nya pulsa high dalam satu priode

\section{METODE PENELITIAN}

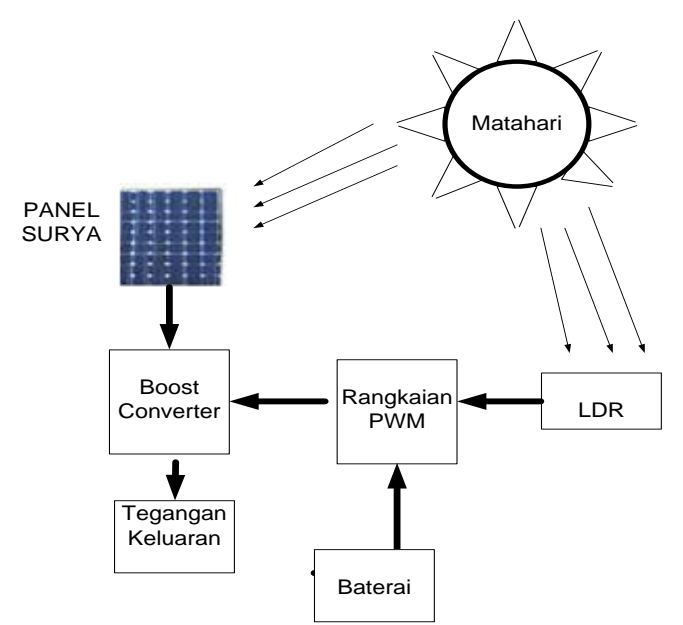

Gambar 5. Alur Skema Penelitian

Penelitian ini dilakukan bagaimana mengkombinasi perubahan intensitas matahari terhadap perilaku panel surya melalui rangkaian boost converter menggunakan LDR sebagai pengatur duty cycle, dimana saat intensitas cahaya berkurang maka resistansi LDR sangatlah tinggi, ini memungkinkan rangkaian PWM untuk melakukan pengaturan duty cycle sinyal PWM, pengaturan ini diharapkan dapat men-switch komponen saklar daya pada rangkaian boost converter sehingga tegangan keluaran dari panel surya menjadi naik. Kenaikan tegangan ini selanjutnya akan diregulasi untuk keperluan charger pada baterai, yang mana baterai digunakan sebagai sumber catu daya pada rangkaian PWM dan dikonsumsi sebagai sumber catu daya. Gambar 6 dibawah menjelaskan cara kerja dari rangkaian PWM yang difungsikan LDR sebagai pengatur duty cycle[4].

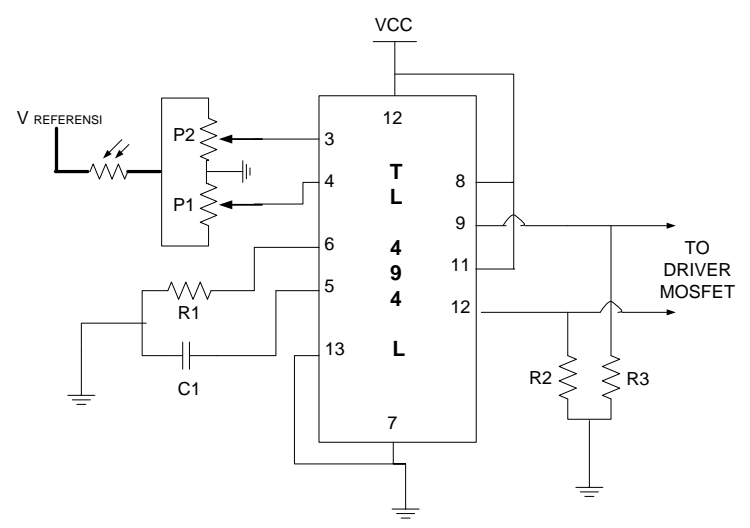

Gambar 6. Rangkaian PWM

Sinyal PWM yang dibangkitkan IC TL 494 L ini kemudian diperuntukan sebagai masukan dari rangkaian driver gate MOSFET, adapun rangkaian driver gate MOSFET seperti diperlihatkan pada gambar 7 dibawah. Rangkaian gate driver ini dibangun dengan menggunakan IC IR2110 [5]. 


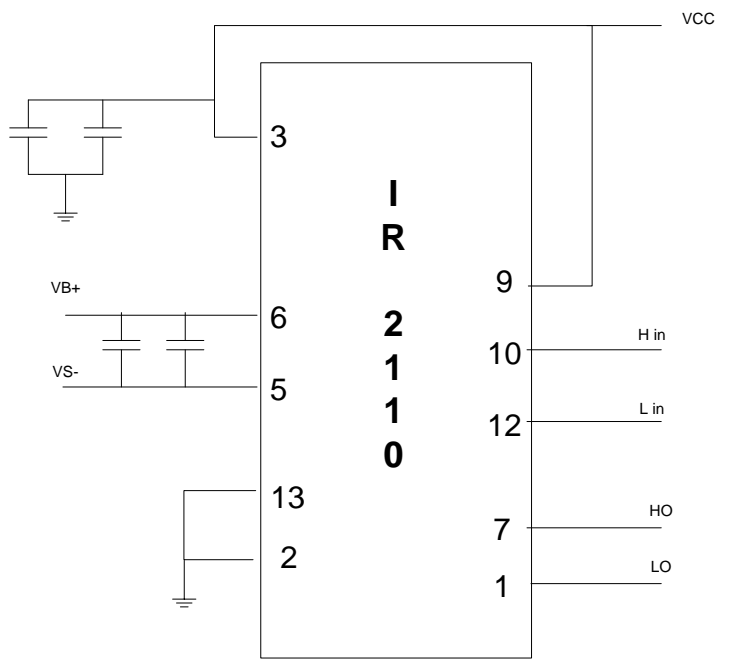

Gambar 7. Rangkaian Driver gate MOSFET

Dari gambar 7 diatas HIN dan LIN adalah masukan dari IC IR 2110 dimana masukan ini diperoleh dari keluaran IC TL 494 L, sedangkan HO dan LO adalah keluaran dari IC IR 2110 yang diperuntukan sebagai masukan dari gate MOSFET pada rangkaian daya Boost Converter.

\section{HASIL DAN PEMBAHASAN}

Untuk mendapatkan hasil dari penelitian ini, pengujian dilakukan dengan mengambil data selama 4 hari yang dimulai pada pukul $9^{00}$ WIB - $15^{00}$ WIB, dengan asumsi agar intensitas matahari yang didapat pada kondisi optimal.

\subsection{Pengujian LDR Sebagai Kendali duty cycle}

Pada Penelitian ini LDR digunakan sebagai pengatur duty cycle melalui perubahan besar tahanan terhadap pengaruh intensitas matahari. Rangkaian penempatan LDR menggunakan IC TL 494 L seperti ditunjukan gambar 6 pada bab sebelumnya. Adapun pengujian yang dilakukan dengan memberikan intensitas cahaya terhadap LDR kemudian melakukan pengukuran menggunakan osciloscop yang mana setting dilakukan, TIME/DIV $=20 \mu \mathrm{s}$ dan $\mathrm{VOLT} / \mathrm{DIV}=5 \mathrm{~V}$, adapun hasil pengukuran berturut-turut ditunjukan pada gambar 8, gambar 9, gambar 10, dan gambar 11.

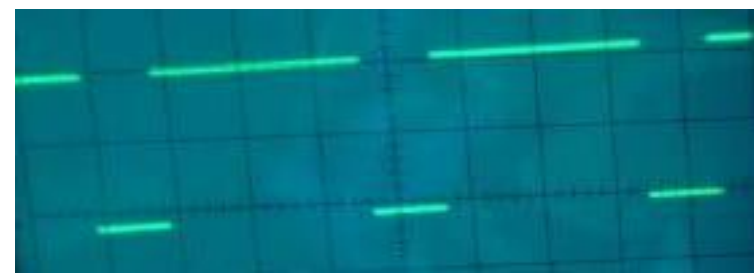

Gambar 8. duty cycle pada tahanan 393 Ohm

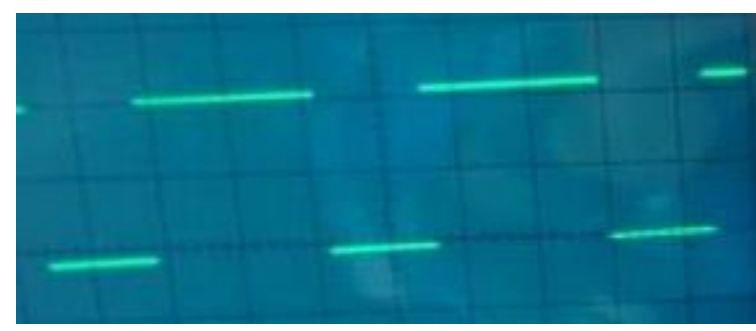

Gambar 9. duty cycle pada tahanan $124 \mathrm{Ohm}$

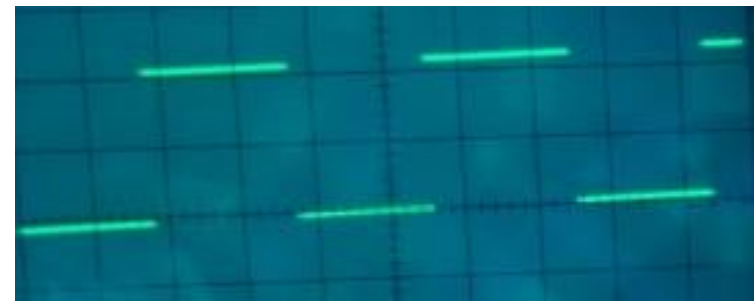

Gambar 10. duty cycle pada tahanan $64 \mathrm{Ohm}$

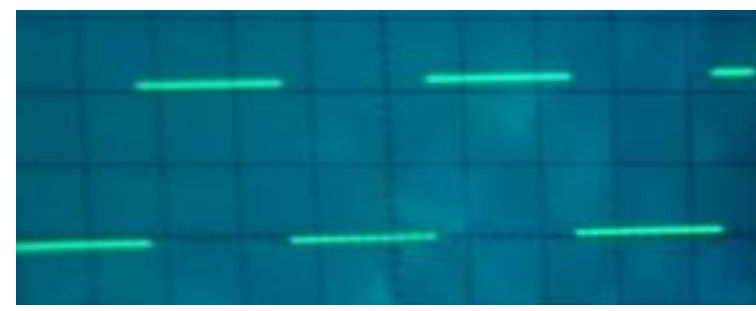

Gambar 11. duty cycle pada tahanan $53 \mathrm{Ohm}$

Dari gambar 8,9,10 dan 11 diatas sinyal PWM mempunyai frekuensi sebesar $12,5 \mathrm{KHz}$ sedangkan perubahan duty cycle terjadi pada $45 \%$ sampai $80 \%$. besaran perubahan duty cycle ini akan memberikan kenaikan tegangan pada rangkaian Boost Converter.

\subsection{Pengujian Keluaran Tegangan Boost Converter}

Pada penelitian ini, kapasitas panel surya yang digunakan adalah $3 \mathrm{Wp}$ dengan tegangan pada daya maksimum (Vmp) adalah 10 volt dan arus pada daya 
maksimum (Imp) adalah 0,334 Amper, dimana pengujian dilakukan selama 4 hari berturut-turut guna mencari besar intensitas matahari yang paling optimal, setelah didapat keadaan intensitas matahari yang paling optimal maka dijadikan sebagai objek atau target dari penelitian ini. Rangkain Daya Boost Converter dan masing-masing besaran nilai komponen yang digunakan diperlihatkan pada gambar 12 dibawah

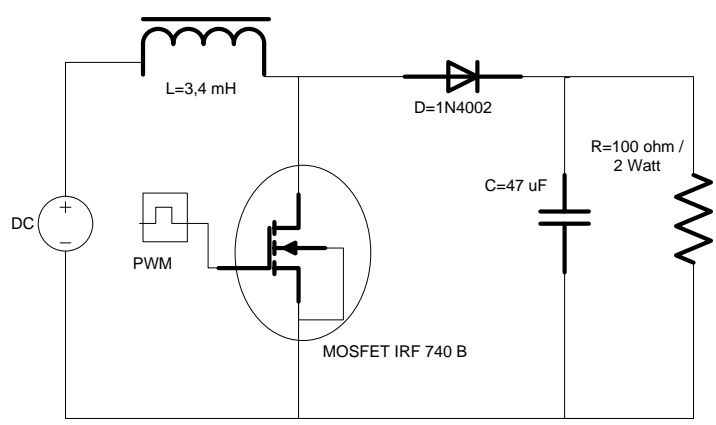

Gambar 12. Rangkaian Daya Boost Converter

Pada gambar 12 rangkaian daya Boost Converter yang ditunjukan diatas pengaturan duty cycle gelombang PWM pada gate kaki MOSFET (saklar daya) berdasarkan dari besar intensitas matahari sehingga nantinya didapat seberapa besar pengaruh dari duty cycle gelombang PWM untuk menaikan keluaran tegangan panel surya.

Adapun hasil pengujian keluaran rangkaian Boost Converter yang paling optimal seperti dijelaskan pada tabel 1 dibawah.

Tabel 1. Data Pengujian

\begin{tabular}{|l|l|l|c|c|c|}
\hline NO & $\begin{array}{l}\text { Waktu } \\
\text { (WIB) }\end{array}$ & $\begin{array}{l}\text { Intensitas } \\
\text { Cahava } \\
\text { Matahari (LUX) }\end{array}$ & $\begin{array}{l}\text { Teg. } \\
\text { Cell (Volt) }\end{array}$ & $\begin{array}{l}\text { Teg. } \\
\text { Boost } \\
\text { (Volt) }\end{array}$ & $\begin{array}{l}\text { Arus } \\
\text { (mA) }\end{array}$ \\
\hline 1 & $\begin{array}{l}10.35- \\
11.05\end{array}$ & 30900 & 6 & 8.4 & 45 \\
\hline 2 & $\begin{array}{l}11.05- \\
11.35\end{array}$ & 31500 & 6.2 & 7.4 & 25 \\
\hline 3 & $\begin{array}{l}11.35- \\
12.05\end{array}$ & 32900 & 8.2 & 10.5 & 50 \\
\hline 4 & $\begin{array}{l}12.05- \\
12.35\end{array}$ & 90600 & 9.7 & 14.3 & 110 \\
\hline 5 & $\begin{array}{l}12.35- \\
13.05\end{array}$ & 34200 & 9.3 & 13,6 & 70 \\
\hline
\end{tabular}

Pada tabel 1 diatas, pengujian dilakukan selama 2,5 jam, dimana pengambilan data dilakukan setiap 0,5 jam. Kecenderungan koefisien determinasi tegangan keluaran panel surya terhadap perubahan intensitas matahari ditunjukan pada gambar 13 sedangkan kecenderungan koefisien determinasi tegangan keluaran boost converter terhadap perubahan intensitas matahari ditunjukan pada gambar 14 dibawah.

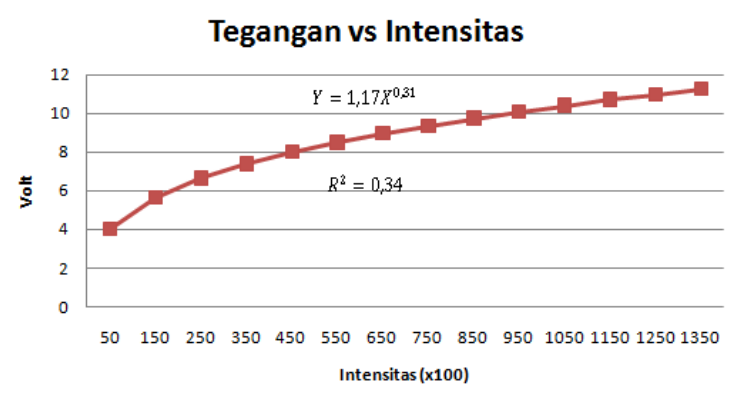

Gambar 13. Keluaran Panel Surya

Dari gambar 13 diatas, didapat fungsi exponensial $\quad Y=1,17 X^{0,31}$ dengan koefisien determinasi sebesar 0,34.

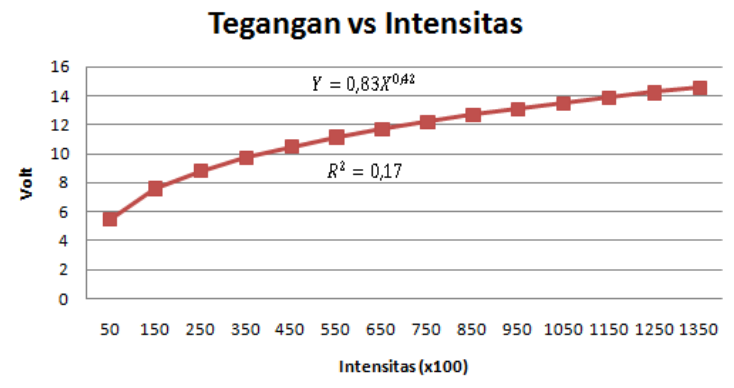

Gambar 14. Keluaran Boost Converter

Dari gambar 14 diatas, didapat fungsi exponensial $\quad Y=0,83 X^{0,43}$ dengan koefisien determinasi sebesar 0,17 .

\section{SIMPULAN}

a. Perancangan Boost Converter dengan LDR sebagai pengendali sinyal PWM untuk optimasi panel surya mampu menaikan tegangan keluaran pada panel surya

b. Intensitas matahari cendrung fluktuatif sehingga energi listrik yang dihasilkan panel surya tidak konstan. 


\section{DAFTAR PUSTAKA}

[1]. Design Calculation For Buck-Boost Converters by Texas Instrumen, 2012.

[2]. Dr.Awang/Dr.Zainal, Power Electronics and Drivers, 2009.

[3]. TL494 Pulse-Width-Mosulation Control Circuits by Texas Instrumen, 2017.

[4]. Hendi Matalata, "Analisa Buck Converter Dan Boost Converter Pada Perubahan Duty Cycle Pwm Dengan Membandingkan Frekuensi Pwm 1.7 $\mathrm{KHz}$ Dan $3.3 \mathrm{KHz}$, "Jurnal Ilmiah Universitas Batanghari Jambi, Vol:18, No.1, Februari 2018.

[5]. Hendi Matalata, "Pengembangan Topologi Inverter Multilevel Tiga Tingkat Satu Fasa Tipe Diode Clamped Dengan Mereduksi Komponen Saklar Daya", JNTE, Vol:5, No.3, November 2016. 